\title{
An Analysis on the Contents of the Stele of Koguryŏ in Ji'an with Regard to Koguryŏ's Reorganization of Sumyoje
}

\section{Introduction}

“Kwanggaet'owangbi (廣開土王碑; the Stele of King Kwanggaet'o)", has been a controversial topic in East Asian scholarship for decades. The stele is a major primary source for examining the history of Koguryŏ (高 句麗) in the fifth century and international relationships among the ancient states in East Asia. Until now, the studies on the stele amongst East Asian scholars have generally focused on political or diplomatic matters of Koguryŏ and other states such as the relationship between the ancient Korean and Japanese states, or Koguryŏ's militaristic expansion in this period. After a number of other primary sources related to the stele were found or excavated, however, many significant studies have been able to deepen our understanding about Koguryǒ in this period. A newfound copy of a rubbing of the stele called 'Hyejŏngbon (惠靜本) $)^{2}$ is one of

* Ph.D. Student, Department of Korean History, Korea University, Seoul, South Korea

1 The stele is also called as "Kwanggaet'otaewangbi (廣開土大王碑; the Stele of Great King Kwanggaet'o).” In China, it is named as "Haotaiwangbei (好太王碑; the Stele of King Ho)." This paper will use the term "the Stele of King Kwanggaet'o" from here on.

2 For more information about Hyejŏngbon, see Sŏ Yŏngsu, "Kwang- 
these sources that allows for a new interpretation of the contents of this epigraph, and as a result, has revitalized discussion about the contents and historical context of the stele. Yet, while the lively debates about this rubbed copy provide valuable information for interpretation of the stele's inscription, it shows the academic circle's interest is still focused on particular issues such as the controversy over the 'Sinmyo year passage (辛印 年條), a short sentence which describes the relationship of Koguryŏ, Wa (Japan), Paekche, and Silla in the $4^{\text {th }}$ century. ${ }^{3}$

In this sense, a stele named “the Stele of Koguryŏ in Ji'an (集安高句麗

gaet'owangrŭngbi Hyejŏngsochangbon: Konggaeŭi Ŭiŭiwa Kŭ Sŏnggyŏk (The Meaning of the Opening to the Public of the Rubbing-inscription from the Original Tombstone for the Great King Kwanggaet'o Housed by Hye-Jung)," Pangmulgwanhakpo (Journal of Museum Studies) 23 (2012). Still, as the problem in interpretation remains, the debate over the passage continues.

3 As there are hundreds of articles about the stele that this paper cannot possibly review exhaustively, it is notable that the most popular topic in this field is undoubtedly the controversy over the Sinmyo year passage. For more information about the historiography of the Stele of King Kwaggaet'o until 1996, see Koguryŏyŏn'guhoe, ed., Kwanggaet'ohot'aewangbi Yŏn'gu 100nyŏn (100 Years of Studies about the Stele of King Kwanggaet'o) (Seoul: Hagyŏnmunhwasa, 1996). For the latest historiography of the stele, please see the Vol. 49 (2015) issue of Tongbugayŏksanonch'ong. It covers the historiography of the stele in various topics. Jung Hosub, “Kwanggaet'owangbiŭi Hyŏngt'aewa Wich'i, Pimun Kusŏnggwa Sŏnggyŏge Kwanhan Yŏn'gu Sŏnggwawa Kwaje (Research on the King Gwanggaet'o Stele and Future Tasks: Regarding Morphology, Location, Content Structure, and Features)"; Jo Yeongkwang, "Kwanggaet'owangbie Poinŭn Taeoe Kwan'gyewa Koguryŏ Ch'ŏnhagwane Taehan Yŏn'gu Hyŏnhwanggwa Kwaje (Status and Tasks for Study of the Foreign Relations and World View of Koguryo in the Gwanggaet'o Stele)"; Lee Jeongbin, “Kwanggaet'owangnŭngbi T'akpon Yŏn'gubangbŏbŭi Sŏnggwawa Kwaje (Research Methods for Rubbings of the Gwanggaeto Stele)"; Cho Wooyun (Zhao Yu-Ran), "Chunggukhakkyeŭi Kwanggaet'owangbi Yŏn'gu Sŏnggwa Kŏmt'o (Review of Historical Research on the King Gwanggaet'o Stele by Chinese Academics)"; Inoue Naoki, "Ilbonhakkyeesŏŭi Kwanggaet'owangbi Yŏn'guŭi Sŏnggwawa Kwaje (Results and Topics in Japanese Research on the Epitaph of King Gwanggaet'o)." 
碑; Chiban Koguryŏbi in Korean)," found in 2012, is a primary source that has potential to broaden our perspective, especially, on the topics about domestic administration in Koguryŏ. Koguryŏ operated an administrative system called Sumyoje (守墓制) that selected commoners to guard the royal tombs under certain laws to control and punish them. Until recently, the discussion about Sumyoje arguably came to a stalemate despite a considerable number of articles analyzing these custodians of the royal tombs because the Stele of King Kwanggaet'o has been the only source to examine the system. Yet, since the contents of this newfound stele also demonstrate the rules of the system, it is now possible to suggest a different characteristic about this system.

Although the date and purpose of the stele is still in debate, scholars generally agree that the purpose of the stele is related to the custodians for the royal tombs. Naturally, most of the recent articles about the newfound stele have addressed this system, broadening our perspective on Koguryŏ's domestic administration. Still, as these articles are generally focused on the date and purpose of the stele, it is hard to say that the academic circle has paid enough attention to the stele's characteristics that suggests Koguryŏ's social circumstances in general, even though there are a number of clues on the inscription to shed light on the social situation in Koguryŏ in the fifth century. For example, the stele reveals a phenomenon that people "buy and sell" the custodians, and as a result, caused confusion in this system. Arguably, the stele is strongly related to the government of Koguryŏ's attempt to prevent this turmoil, which is in line with its struggle to control the populace through a centralized government.

To prove this hypothesis, this paper will first review previous research about the custodians of the royal tombs in Koguryŏ the Stele of King Kwanggaet'o illustrates before the Stele of Koguryǒ in Ji'an was found. Then it will introduce and analyze the Stele of Koguryŏ in Ji'an, focusing on the parts of the inscriptions in regard to Sumyoje, and laws applied to the custodians. Finally, the paper will describe the possible social circumstances in Koguryŏ to enact these laws, which was linked to the inflow of population after King Kwanggaet'o's militaristic expansion. 


\section{The Stele of King Kwanggaet'o and Discussions about the Custodians of the Royal Tombs}

As is well known, the Stele of King Kwanggaet'o is a stone slab erected by his son, King Changsu (長壽王), commemorating his father in 414 AD. ${ }^{4}$ The inscription of the stele, which consists of 1,775 Chinese characters estimated by scholars, is generally grouped by content into three categories: 1) Koguryŏ's foundation myth, 2) King Kwanggaet'o's martial achievements, and 3) rules and members of the custodians assigned for the king's tomb. About the foundation myth, the inscription demonstrates the legend of Koguryŏ's founder and lineage from the founder to King Kwanggaet'o. Then the inscription continues with the king's martial accomplishments starting with the subjugation of Paeryo (稗麗) in 395. The records about King Kwanggaet'o's conquests are mainly names of the castles he occupied and other states' submission to his authority like Paekche's surrender to Koguryŏ in 396. The third part covers appointments and regulations on the custodians for the king's tomb. The custodians of the tomb, called Sumyoin (守墓人; a protector of the tomb), have a household as a unit. ${ }^{5}$ The total number of the households for the job was 330 , and according to the inscription 220 households were from the territories the king conquered. The text ends with the regulations on the administration of these custodians, which was instructed by the king when he was alive. ${ }^{6}$

It is true that a few limited topics have dominated the historiography of the stele for decades such as the famous debate over the Sinmyo year passage (辛卯年條), and scholars had taken relatively little interest in other

4 For the measurement and general information about the stele, see Noh Tae don, "Kwanggaet'owangbi," in Yǒkcho han'gukkotaekŭmsŏkmun 1 (Ancient Epigraph of Korea, Vol.1), ed. Han'gukkotaesahoeyŏn'guso (Seoul: Karakkusachŏkkaeparyŏn'guwŏn, 1992), 3-5.

5 "Sumyoin" could be translated as 'a protector of tombs', 'custodian of tombs', or 'tomb keeper.' This paper will use the term 'custodian.'

6 Noh, "Kwanggaet'owangbi," 5. 
issues about the stele. Still, there is a significant amount of research that attempts to analyze Koguryŏ's social structure and administration reflected in the inscription, and discussion about the custodians (Sumyoin) is one of these attempts that have drawn the Korean academy's attention for decades. As noted above, half of the inscription posts the number and background for the custodians in detail. ${ }^{7}$ At the end of these lists, there is a passage about the new rules and regulations to the custodians as in the following:

(A-1)

When Great King of Kukkangsang Kwanggaet'o Ho (國岡上廣開土境好太王) was alive, he issued a royal command (敉) that says, “(1) our ancestor kings (祖王先王) had only brought the Old People (舊民) and had them guard and clean(酒掃) the tombs. I am worried that these Old people will be gradually impoverished. For the job to guard my tomb in peace after my days are over, (you) will bring people of Han and Ye whom I personally went and captured, and make them guard and clean my tomb." Since his majesty's words were (stated) as above, (we) brought 220 households of Han and Ye, and made them guard the tomb. Yet, fearing that those people of Han and Ye may not know the formalities of the custodians, (we) brought 110 households from the Old People again (and made them the custodians). With the new and old households of the custodians altogether, 30 households are Kugyŏn (國烟), while 300 households are Kanyŏn (看烟). The total number of the households is 330 .

Since our ancestor kings had not erected a stone stele at the royal tombs, Yŏnho of the custodians had been deviated and confused.

7 For the detailed information about the list of the custodians before A-1, please see Lim Ki Hwan, “Koguryŏ Chipkwŏnch'eje Sŏngnipkwajŏngŭi Yŏn'gu (A Study on the Process of Koguryŏ's Formation of the Centralized System)" (PhD diss., Kyŏnghui University, 1995), 171. 
Only Great King of Kukkangsang Kwanggaet'o Ho ordered the building of steles for ancestor kings, and recording the Yŏnho in order to prevent confusion. Also, his majesty enacted (a law) that "from now on, the custodians will not be sold to each other, and bought by anyone even if he is wealthy. If anyone disobeys this law, the seller will receive a punishment, and the buyer will be obligated to take the job of the custodian for himself. ${ }^{8}$

This record, which has been the only historical source to mention the domestic administration written by people in Koguryŏ themselves, did not only announce the law, but also illustrates the situation that they had to reform the system at the time. According to this record, there were a number of problems in the old custodian system and King Kwanggaet'o reorganized the system during his lifetime; first, the previous kings in Koguryŏ only assigned the "Old People (舊民)," which refers to the original residents within Koguryǒ's territory before King Kwanggaet'o's conquest of the other regions, to duties of the custodians. King Kwanggaet'o was worried that these people may suffer impoverishment, and he ordered to use people in the areas he conquered as custodians. Second, as the other kings had never erected steles to register the custodians, there was 'deviation and confusion' in the system. It is uncertain what sorts of problems had occurred without a stele to record the custodian, but the king ordered to erect a stele for the royal tombs in order to prevent this confusion. Thirdly, King Kwanggaet'o enacted a law to prohibit selling and buying the custodians, and a certain punishment to the law-breakers; if

8 The original text of the inscription is as in the following: “國罡上廣開土境好太王 存時敉言 祖王先王 但敎取遠近舊民 守墓酒掃 吾慮舊民轉當贏劣 若吾萬年之後 安 守墓者 但取吾躬巡所略來韓穢 令備酒掃 言呚如此 是以如呚令 取韓穢二百廿家 慮 其不知法則 復取舊民一百十家 合新舊守墓戶 國烟卅看烟三百 都合三百卅家 自上祖 先王以來 墓上不安石碑 致使守墓人烟戶差錯 唯國罟上廣開土境好太王 盡爲祖先王 墓上立碑 銘其烟戶 不令差錯 又制 守墓人 自今以後不得更相轉賣 雖有富足之者 亦不得擅買 其有違令 賣者刑之 買人制令守墓之.” 
there was anyone who violated this order, the seller would receive a certain punishment, and the buyer would be obligated to carry out the duty instead.

Although the inscription about this part is clearly deciphered, the interpretation of the passage is still in debate, since there were many unclear terms to understand the overall context of the system. First of all, the exact meaning of 'Kugyŏn (國烟)', and 'Kanyŏn (看烟)' is still unclear; although it is generally agreed that 'Yŏn (烟)' or 'Yŏnho (烟戶)' is a unit name referring to a custodian's household, the inscription does not explain how to differentiate 'Kugyŏn' from 'Kanyŏn.' It is likely that 'Kugyŏn' is a unit of the custodians that has a supervisory role over 'Kanyŏn' in consideration of their numbers. Some historians like Pak Sihyŏng suggested that these terms are names of the units that compose a team, which consist of one 'Kugyŏn (國烟)' and ten 'Kanyŏn.' In total, there were 30 units of the custodians according to the stele's content. ${ }^{9}$

The second problem in this passage is the social status of these custodians. Since the overall description of the custodians' duties signifies forced labor, the custodians were apparently selected from the commoners in Koguryŏ. Yet, considering the regulation to prohibit 'selling and buying the custodians,' or the order to recruit people from the conquered territories, the features of these custodians corresponds to prisoner of war, or even slave status. Historians like Park Chinsŏk ${ }^{10}$ or Kim Hyŏnsuk ${ }^{11}$ emphasize these facets and argue that the custodians were slaves, or groups of people who had a lower social status than average commoners in Koguryŏ. On the other hand, other scholars like Kim Sŏkhyŏng insist that

9 Park Sihyŏng, Kwanggaet'owangrüngbi (The Stele for the Royal Tomb of King Kwanggaet'o) (Pyongyang: Sahoekwahagwŏn Chulp'ansa, 1966).

10 Park Chinsŏk, Koguryŏ Hot'aewangbi Yŏn'gu (A Study on Hot'aewangbi of Koguryŏ) (Seoul: Aseamunhwasa; 1996), 343-62

11 Kim Hyŏnsuk, “Kwanggaet'owangbirŭl T'onghaepon Koguryŏsumyoinui Sahoechŏk Sŏnggyŏk (The Social Characters of the Tomb Keepers Illumined through the Great King Kwanggaet'o's Stele)," Han'guksayŏn'gu (The Journal of Korean History) 65 (1989). 
those custodians were not slaves, since they were running 'households,' implying they had a certain amount of private property. ${ }^{12}$ Park Sihyŏng also suggested that the custodians were not slaves but commoners under forced labor conditions with limited freedom. ${ }^{13}$

The controversy over the passage fundamentally emerges from different interpretations on the sentence to prohibit the selling and buying of the custodians, as it signifies the possibility that people who were assigned to the duties of the custodians were possibly subject to human trafficking. Accordingly, many historians have argued these custodians were originally slaves, or specific groups who had lower social status than other commoners in Koguryŏ. On the other hand, historians who deny the custodians were slaves suggest that the sellers in the inscription refers to the custodians themselves, and that they were commoners selling their manpower and taking the duties instead of the buyers. ${ }^{14}$

Still, it is hard to imagine that the custodians were slaves or people with a lower social status than other commoners in Koguryŏ. If the custodians were slaves or captives, they would have been treated as property of the royal court or aristocrats in Koguryŏ. In this case, it would be incomprehensible that King Kwanggaet'o suddenly forbade trading the custodians, as they would have been considered personal property from the outset. Furthermore, according to (1) in A-1), King Kwanggaet'o noted his concern for the custodians suffering from gradual impoverishment. If their social status was as low as slaves or war slaves, it is unlikely that the king would make such a remark or prepare a countermeasure against poverty. Thus, the custodians were arguably average commoners, and the royal court of Koguryŏ recruited the custodians to guard the royal tombs

12 Kim Sŏkhyŏng, Ch'ogijoilgwan'gyesa (The Early Korean-Japanese Relationship) (Pyongyang: Sahoekwahagwŏn Chulp'ansa, 1966).

13 Park Sihyŏng, Kwanggaet'owangrŭngbi, 226.

14 Lim, "Koguryŏ Chipkwŏnch'eje," 183-86. The paper reviews the previous studies' discussions about the definition of "selling and buying the custodians." 
from commoners. ${ }^{15}$

Moreover, it is more likely that these custodians carried out their duties while living in the area where royal tombs were constructed. Some historians insist that the custodians basically lived in their hometown, and temporarily moved to the capital to carry out their duties when their turn came. ${ }^{16}$ Yet, not only is this method inefficient, it would inevitably cause confusion in the process of transferring the custodians, as they were selected from every corner of the kingdom according to the inscription of the stele. ${ }^{17}$ Therefore, it would be more reasonable that these custodians were residents moved to the capital city, and used as labor by the royal court of Koguryŏ.

Although there were many studies focusing on this topic, the debate over the exact characteristics of the custodians is uncertain as there is no other historical record about the custodians during Koguryŏ except fragments of texts in other historical books like Samguksagi (History of The Three Kingdoms, 三國史記); practically, the Stele of King Kwanggae'to

15 Although this paper argues that the custodians were fundamentally commoners, it would require an answer to the counterarguments from previous studies, such as why there is a division of among the custodians 'Kugyŏn' and 'Kanyŏn,' since it implies that there was a disparity in social standing among the custodians. To explain and confirm the social status of the custodians, it would be necessary to understand the overall class system and social structure of Koguryŏ during this period. Still, this paper will omit this discussion due to a lack of space and follow the previous studies that view the custodians' status as commoners. For the discussions about the social status of the custodians in other studies, see Kim Rak Ki, “Kwanggaet'owangbi sumyoinyŏnhojoŭi yŏn'guhyŏnhwanggwa kwaje (The Current Status and Tasks of Sumyoin-yunho (守墓人烟戶) in King Gwanggaet'o stele)," Sónsawa kodae (Prehistory and Ancient History) 47 (2016): 40-53.

16 Son Yŏngjong, "Kwanggaet'owangnŭngbimune Poinŭn Sumyoinyŏnho Ŭi Kyegŭpchŏk Sŏnggyŏkkwa ribyŏkpangsige taehayŏ (About the Sumyoin yŏnho's Hierarchical Characteristic and the Method to Carry out the Duty Reflected on the Stele of King Kwanggaet'o)," Ryŏksagwahak (Historical Science) 3 (1986).

17 As noted, the stele records the administrative districts where the custodians were transferred, and the total number of the districts was 50 . 
has been the only source to examine the system of the custodians in Koguryŏ. Yet, after the Stele of Koguryŏ in Ji'an, a stone slab erected around the same time as the Stele of King Kwanggaet'o, was excavated at Ji'an city in 2012, it provides a chance to revisit the question about the custodians in Koguryŏ. In the following section, this article will examine the Stele of Koguryŏ in Ji'an in detail and analyze its characteristics in order to make preliminary conclusions regarding the custodians of Koguryŏ, and ultimately the assumed social situation during this period.

\section{"The Stele of Koguryŏ in Ji’an" and the Controversy over its Inscription}

The Stele of Koguryŏ in Ji'an, originally found in the riverbank of the Maxian River (麻线河), Ji'an County, Jilin Province, is a stele made of granite. The height of the stele is $173 \mathrm{~cm}$ (around $5.68 \mathrm{ft}$ ), the width $42 \mathrm{~cm}$, and thickness $21 \mathrm{~cm}$, with a weight of $464.5 \mathrm{~kg}$. Although it is suggested that there were letters engraved on the back and front, the letters on the back are mostly illegible. ${ }^{18}$

The number of characters of the inscription on the front was assumingly 218 in total. After the official report from Ji' an City Museum (集安市博 物館) provided 156 characters deciphered, many scholars presented interpretations of the inscription, reportedly deciphering from 162 to 217 letters. For the rubbings of the stele, there are currently 15 different copies reported. ${ }^{19}$ The original text and interpretation of the inscription are as in the following:

18 For the process of the excavation of the stele, see Lee Yŏngho, "Chiban koguryŏbiŭi palgyŏn'gwa sogae (Discovery and Introduction of the stele of Koguryŏ in Jian)," Han'gukkotaesayŏn'gu (The Journal of Ancient Korean History) 69 (2013).

19 For more information about the rubbings of the stele, please see Yun Yong-gu, “Jian Koguryŏpiŭi T'akpongwa P'andok (Rubbing and Deciper of the Stele of Koguryŏ in Ji'an)," Han'gukkotaesayŏn'gu (The Journal of Ancient Korean History) 70 (2013). 
Figure 1. The Stele of Koguryŏ in Jian and the Excavation Site ${ }^{20}$
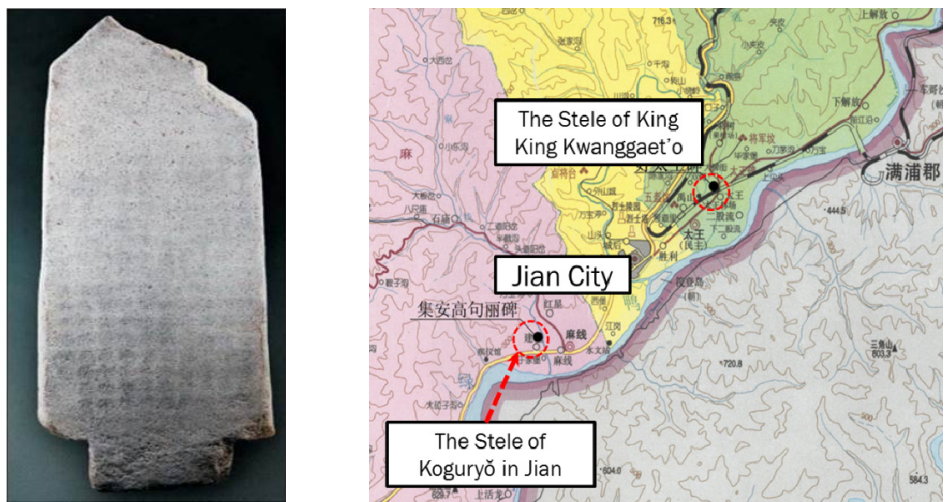

Table 1. The inscription's original text ${ }^{21}$

\begin{tabular}{|c|c|c|c|c|c|c|c|c|c|c|}
\hline $\mathrm{X}$ & IX & VIII & VII & VI & V & IV & III & II & I & \\
\hline 賣 & 守 & $\square$ & $\square$ & $\square$ & $\square$ & $\mathbf{\square}$ & $\mathbf{\square}$ & 口 & $\square$ & 1 \\
\hline 因 & 墓 & $\square$ & $\square$ & $\square$ & $\square$ & $\square$ & $\square$ & $\bar{\square}$ & $\square$ & 2 \\
\hline 若 & 之 & $\square$ & $\square$ & $\square$ & $\square$ & $\square$ & $\square$ & $\square$ & $\square$ & 3 \\
\hline 違 & 民 & $\square^{22}$ & 好 & $\square$ & $\square$ & $\square$ & $\square$ & 子 & $\mathbf{\square}$ & 4 \\
\hline 令 & 不 & 立 & $\square^{23}$ & $世^{24}$ & $\square$ & 烟 & 各 & 河 & 世 & 5 \\
\hline 者 & 得 & 碑 & $\square$ & 室 & 王 & 戶 & 墓 $^{20}$ & 伯 & 必 & 6 \\
\hline 後 & 擅 & 銘 & 王 & 追 & 國 & $\square$ & 烟 & 之 & 授 & 7 \\
\hline 世 & 買 & 其 & 曰 & 述 & 岡 & 劣 & 户 & 孫 & 天 & 8 \\
\hline$\square$ & 更 & 烟 & 自 & 先 & 上 & 甚 & 以 & 神 & 道 & 9 \\
\hline 嗣 & 相 & 戶 & 戊 & 聖 & 太 & 衰 & $\square$ & 靈 & 自 & 10 \\
\hline$\square$ & 轉 & 頭 & $\square^{26}$ & 功 & 王 & 富 $^{27}$ & 河 & 祐 & 承 & 11 \\
\hline$\square$ & 賣 & 廿 & 定 & 勳 & $\square^{28}$ & 足 ${ }^{29}$ & 流 & 護 & 元 & 12 \\
\hline 看 & 雖 & 人 & 律 & 彌 & 平 & $\square$ & 四 & 蔽 & 王 & 13 \\
\hline 其 & 富 & 名 & 教 & 高 & 安 $^{30}$ & 轉 & 時 & 蔭 & 始 & 14 \\
\hline 碑 & 足 & $\square$ & 內 & 悠 & 太 & 賣 & 祭 & 開 & 祖 & 15 \\
\hline 文 & 之 & 示 & 發 & 烈 & 王 & 數 & 祀 & 國 & 鄒 & 16 \\
\hline 与 & 者 & 後 & 令 & 継 & 神 & 衆 ${ }^{31}$ & 然 & 辟 & 牟 & 17 \\
\hline 其 & 亦 & 世 & 更 & 古 & 亡 & 守 & 而 & 土 & 王 & 18 \\
\hline 罪 & 不 & 自 & 脩 & 人 & $\square$ & 墓 & 世 & 継 & 之 & 19 \\
\hline \multirow[t]{3}{*}{ 過 } & 得 & 今 & 復 & 之 & 興 & 者 & 悠 & J幻 & 創 & 20 \\
\hline & 其 & 以 & 各 & 慷 & 東 & 以 & 長 & 相 & 基 & 21 \\
\hline & 買 & 後 & 於 & 慨 & 西 & 銘 & 烟 & 承 & 也 & 22 \\
\hline
\end{tabular}

20 The pictures were from the official report of the stele in China. Jian City Museum, ed., Ji'angaojulibei (The Stele of Koguryŏ in Jian) (Changchun: Jilindaxue Chubanshe, 2013). 
Table 2. The Interpretation of the Inscription (divided by content)

\begin{tabular}{|c|c|c|c|}
\hline & Original Texts & Translation & Note \\
\hline \multirow{2}{*}{$\begin{array}{l}\text { From } \\
\text { I }-1 \\
\text { to } \\
\text { II }-18\end{array}$} & $\begin{array}{l}\mathbf{0} \mathbf{0} \text { 世必授天 } \\
\text { 道自承元王始祖鄒 } \\
\text { 牟王之創基也 }\end{array}$ & $\begin{array}{l}{[\ldots] \text { period(世), taking the heaven's road (天道; or }} \\
\text { heaven's will) by destiny, and succeeding the orig- } \\
\text { inal king (元王), the first ancestor King Ch'umo } \\
\text { (鄒牟王) laid the foundation of (our) state. }\end{array}$ & \multirow{2}{*}{$\begin{array}{l}\text { 1) The } \\
\text { founda- } \\
\text { tion myth } \\
\text { of Kogu- } \\
\text { ryŏ }\end{array}$} \\
\hline & $\begin{array}{l}\text { 口ם } \mathbf{q} \text { 河伯之孫 } \\
\text { 神靈祐護蔽蔭開國 } \\
\text { 辟土 }\end{array}$ & $\begin{array}{l}{[\text { Ch'umo] was }[\ldots] \text { 's son, and grandson of Habaek }} \\
\text { (河伯). With the support from holy spirits and an- } \\
\text { cestors, (he) established the state and expanded the } \\
\text { territory. }\end{array}$ & \\
\hline \multirow{3}{*}{$\begin{array}{l}\text { From } \\
\text { II-18 } \\
\text { to } \\
\text { VI-22 }\end{array}$} & $\begin{array}{l}\text { 継胤相承 } \mathbf{\square} \square \\
\text { 各墓 } \\
\text { 烟户以河流四時 } \\
\text { 祭祀 } \\
\end{array}$ & $\begin{array}{l}\text { (His descendants) succeeded his throne one after } \\
\text { another, each Yoonho (烟户) (resided at the) rivers } \\
\text { and performed rituals for him every season. }\end{array}$ & \multirow{3}{*}{$\begin{array}{l}\text { 2) The } \\
\text { history of } \\
\text { the custo- } \\
\text { dian } \\
\text { system } \\
\text { and the } \\
\text { protago- } \\
\text { nist of the } \\
\text { inscrip- } \\
\text { tions' } \\
\text { achieve- } \\
\text { ment }\end{array}$} \\
\hline & $\begin{array}{c}\text { 然而世悠長烟 } \square \\
\square \square \text { 烟戶口劣甚衰 } \\
\text { 富足 } \square \text { 轉賣數衆守 } \\
\text { 墓者以銘 }\end{array}$ & $\begin{array}{l}\text { Yet, after a long period, they sold Yŏnho and }[\ldots] \\
\text { Yonho, }[\ldots] . \text { The number of (the custodians) rich } \\
\text { people resold (increased, so we) record the names } \\
\text { of (the custodians) and }[\ldots] .\end{array}$ & \\
\hline & 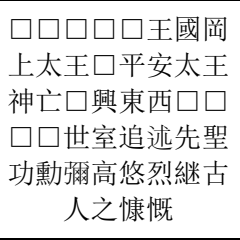 & $\begin{array}{l}{[\ldots] \text { King, the Great King of Kukkangsang, and the }} \\
\text { Great King of }[\ldots] \text { Pyongan's, holy spirits dimin- } \\
\text { ished }[\ldots] \text { flourished in the east and west }[\ldots] \text { the } \\
\text { royal shrine. [...] additionally recorded how the } \\
\text { achievement of the ancestral saint (先聖) is high } \\
\text { and lofty, and succeeded the ancestor's righteous } \\
\text { wrath. }\end{array}$ & \\
\hline \multirow{2}{*}{$\begin{array}{l}\text { From } \\
\text { VII-1 } \\
\text { to } \\
X-20\end{array}$} & $\begin{array}{l}\square \square \square \text { 好 } \square \square \text { 王曰 } \\
\text { 自戊 } \square \text { 定律教內發 } \\
\text { 令更脩復各於 } \square \square \\
\square \square \text { 立碑銘其烟戶 } \\
\text { 頭廿人名 } \square \text { 示後世 }\end{array}$ & $\begin{array}{l}{[\ldots] \text { Ho }[\ldots] \text { King says "after establishing the law }} \\
\text { in the year of Mu(戊) }[\ldots],[\mathrm{I}] \text { issued a royal com- } \\
\text { mand and announced a law to recover it. [We] erect } \\
\text { a stele in each [...], and inscribe the names of } 20 \\
\text { Yornhotu (烟户頭), and show them to our descend- } \\
\text { ants. }\end{array}$ & \multirow{2}{*}{$\begin{array}{l}\text { 3) The } \\
\text { king's } \\
\text { announce } \\
\text { nounce- } \\
\text { ment of } \\
\text { recording } \\
\text { the names } \\
\text { of the } \\
\text { custodi- } \\
\text { ans and } \\
\text { order to } \\
\text { forbid } \\
\text { trading } \\
\text { the custo- } \\
\text { dians. }\end{array}$} \\
\hline & $\begin{array}{l}\text { 自今以後守墓之民 } \\
\text { 不得擅買更相轉賣 } \\
\text { 雖富足之者亦不得 } \\
\text { 其買賣因若違令者 } \\
\text { 後世 } \square \text { 嗣 } \square \square \text { 看其 } \\
\text { 碑文与其罪過 }\end{array}$ & $\begin{array}{c}\text { From now on, (his majesty) forbade to buy or sell } \\
\text { the custodian people (守墓之民) to each other. If } \\
\text { there is anyone who disobeys this law, for genera- } \\
\text { tions they [...], and make inquiry into a crime } \\
\text { according to the stele." }\end{array}$ & \\
\hline
\end{tabular}

While the inscription's number of characters is less than a tenth of the Stele of King Kwanggaet'o's, there are remarkable similarities between 
them. First, the inscription can be divided into three parts like the Stele of King Kwanggaet'o: 1) the foundation myth of Koguryŏ, 2) a personal record of the king the stele was dedicated to, and 3) a list and rule for custodians for a royal tomb. ${ }^{32}$ The stele first illustrates how Koguryŏ's founder established the state, and his descendants succeeded his throne. Although many letters are defaced and illegible in the second part, it is

$21 \square$ refers to a character on the stele broke off, and $\square$ refers to an illegible character. The original text in Table 1 is based on the Yeo Ho-Kyu's interpretation. Yeo HoKyu, 'Han·chung·il Samguk Hakkyeŭi <Chiban'goguryŏbi> Yŏn'gudong hyanggwa Kwaje (Current status and future prospects of studies dealing with the "Koguryo Tablet at Jian" in Korea, China, and Japan)," Tongbanghakchi 177 (2016). Additionally, this table refers to Kang Jin-won, "Sinbalgyŏn 'Chiban'gokuryŏpi'ŭi P'andokkwa Yŏn'gu Hyŏnhwang: Yakkanŭi Nukyŏnŭl tŏtpuch'yŏ (Reading and Analyzing the Newly Discovered JianGoguryeo Bi: the Report of Current Research Situation and the Author's Personal Opinion)," Mokkan'gwa Munja (Wooden Documents and Inscriptions Studies) 11 (2013); Sun Renjie, "Chiban Koguryŏpiŭi P'andokkwa Munja Pikyo (Interpretation and Crosschecking of letters, of the Jian Tablet of Koguryo)," Han'gukkotaesayŏn'gu (The Journal of Korean Ancient History) 70 (2013) ; Yun, "Jian Koguryŏpiŭi T'akpongwa P'andok."

22 Sun deciphered the characters from VIII 1 to VIII 4 as “先王墓上”. This paper leaves it illegible.

23 Yun deciphered the character as '太'. This paper leaves it illegible. See Figure 3.

24 Yun deciphered the character as ‘神'. This paper follows Yeo decipher.

25 Sun deciphered the character as ‘家”, while Yun chose ‘定'. This paper follows Yeo's interpretation.

26 See Chapter 3 and Figure 2. This paper leaves it illegible.

27 Yeo deciphered the character as “當”. This paper follows Yun's decipher.

28 Yun deciphered the character as '國'. This paper leaves it illegible.

29 Yeo deciphered the character as '買'. This paper follows Yun's decipher.

30 Yeo deciphered the character as illegible. This paper follows Sun's decipher.

31 Yeo deciphered the character as illegible. This paper follows Yun's decipher.

32 Kong Seok-koo, “'Chiban Koguryŏpi'ŭi Palgyŏn'gwa Naeyonge Taehan Koch'al (The Discovery and Analysis of Koguryo Tomb-guarding Monument)," Koguryŏ Palhae Yŏn'gu 45 (2013). 
assuredly about the king's achievement and his announcement of the laws about the custodians for the royal tombs. The foundation myth in the stele indicates the same context as the Stele of King Kwanggaet'o such as declaring Habaek, a god of rivers, as the founder's grandfather.

Still, the differences between these two steles are clearly distinct, including the inscription's number of letters. First, while the Stele of King Kwanggaet'o records the king's lineage and martial accomplishments in detail, the Stele of Koguryŏ hardly explains anything about King Kwanggaet'o, or any other kings. It mentions a king who has a title "T'aewang (太王; a Great King)" and his announcements of laws in a few sentences, but it is not definite whether the king in the inscription refers to King Kwanggaet'o. The king in the inscription may refer to preceding kings, because there were a number of kings who had the title of "T'aewang" or "Kukkangsang" in Koguryŏ.

The problem over the identity of the protagonist of the inscription is linked with the date of the stele's erection, which is another topic of controversy over this stele, unlike the Stele of King Kwanggaet'o. There is no clearly deciphered character in the inscription to suggest the date of the erection except ' $\mathrm{Mu}$ (戊)' on the seventh line, a part which describes the king who established a law for the custodians. Although it is obvious that ' $\mathrm{Mu}$ ' is the fifth among the ten celestial stems to indicate a certain year, the exact date the character refers to is unknown because the next character, one of the Earthly Branches, is defaced. Yet, some Chinese historians like Sun Renjie deciphered the fourth to eighth letters on the seventh line of the inscription as “丁卯歲刊石”, and insisted that this part indicates the date of the erection of the stele. According to them, the stele was carved and erected in the $15^{\text {th }}$ year $\left(427\right.$ A.D.) or $75^{\text {th }}$ year $(487$ A.D.) of King Changsu, assuming that "the Great King of Kukkangsang" in the fifth line is a posthumous title for King Kwanggaet'o. ${ }^{33}$

33 Sun, "Chiban Koguryŏpiŭi P'andokkwa Munja Pikyo," 229; Xu Jian-xin, "Zhongguo xinchu Jiangaolulibei shixi (Analysis on the Newly Found the Stele of Koguryŏ in Ji'an of China)," Dongbeishidi (東北史地) 2013-3 (2013): 17-31. 
On the other hand, most scholars in Korea and some Chinese historians argue that the stele was erected during the reign of King Kwanggaet'o, denying the interpretation of the seventh line as “丁卯歲刊石." 34 According to them, since the rules and regulations in the inscription were not as detailed as the Stele of King Kwanggaet'o's, the inscription on the newfound stele should be incised before the other stele. For example, while the Stele of King Kwanggaet'o announces a policy to resolve impoverishment of the Old People, the Stele of Koguryŏ in Ji' an does not address this issue at all. ${ }^{35}$ Some of these historians also suggest that the fourth to eighth letters on the seventh line (VII-4 to VII-8. Figure 2) were “好太星王 曰(King Hotaesŏng says)” or “ $\square$ 好太 $\square$ 王曰(King Hotae[...] says),” which indicates that the inscription is an announcement of the royal order from King Kwanggaet'o himself. Thus, these historians insist that the stele was erected during King Kwanggaet'o's reign, and "the Great King of Kukkangsang" in the fifth line is a posthumous title for his preceding kings, such as King Kogugwŏn (故國原王) or King Kogukyang (故國壤 王). Additionally, they argue that the character after ' $\mathrm{Mu}$ ' is 'Cha (子) or 'Shin (申)'(VII-11. Figure 3), which makes the year of Mucha (戊子; 388 A.D.), or Mushin (戊申; 408 A.D.).

Meanwhile, scholars generally agree that the purpose of the stele is related to the custodians for the royal tombs. The legible content mainly

34 Yeo Ho-Kyu, "Sinbalgyŏn 〈Chiban'goguryŏbi〉ŭi Kusŏnggwa Naeyong Koch'al (Examination of the Composition and Contents of the Newly found <Koguryo Tablet of Jian>)," Han'gukkotaesayŏn'gu (The Journal of Ancient Korean History) 70 (2013); Zhao Yu-Ran, "Chiban Koguryŏbie Nat'anan Wangnŭngjesawa Chosanginsik (The Ritual of Royal Tombs and Perception of Former Kings Reflected in 'The Ji-an Koguryo Stele)," Han'gukkotaesayŏn'gu (The Journal of Ancient Korean History) 70 (2013).

35 Hong Seung-Woo, “〈Chiban'goguryŏbi >e Nat'anan Koguryŏ Yullyŏngŭi Hyŏngsikkwa Sumyoje (Law Codes and System for guarding and managing royal tombs of Goguryeo, reflected upon Jian-Goguryeo-Stele)," Han'gukkotaesayŏn'gu (The Journal of Ancient Korean History) 72 (2013). 
Figure 2. Enlarged Images of the Letter from VII-4 to VII-8 in the Stele's Rubbing ${ }^{36}$
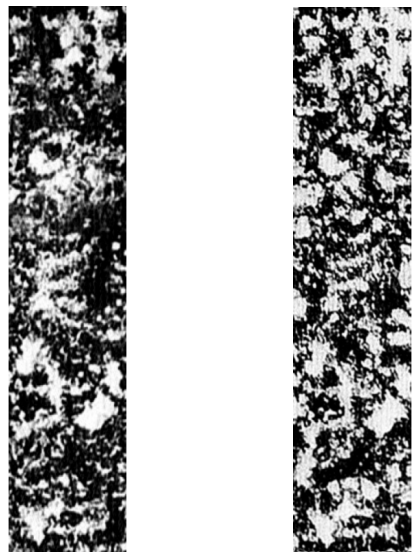

Figure 3. Enlarged Images of VII-11 in the Stele's Rubbing ${ }^{37}$
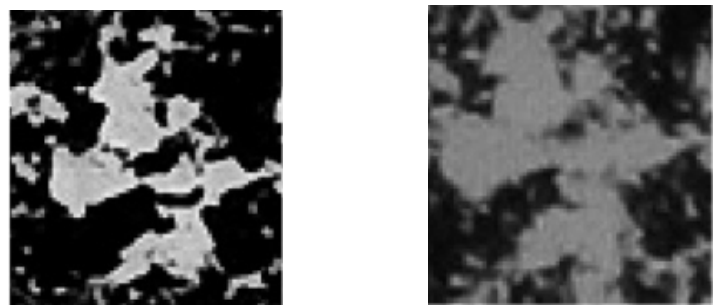

describes a king establishing a law to forbid people from selling and buying the custodians. Compared to the long list of the custodians inscribed on the Stele of King Kwanggaet'o, the Stele of Koguryŏ in Ji'an does not show any names or the background of the custodians. Yet, on the back face of the stele, there is a legible Chinese character meaning "in total (合)," indicating that there was a list of the custodians written on the back

36 Left: Rubbing made by Zhou Rongshun (周榮順) in 2012. Right: Rubbing made by Jiang Huaguo (江化國) and Li Guanfu (李光夫) in 2012.

37 Left: Rubbing made by Zhou Rongshun in 2012. Right: Rubbing made by Jiang Huaguo and Li Guanfu. These images were quoted from Yun, "Jian Koguryŏpiŭi T'akpongwa P'andok." For the whole picture of the rubbing, see Figure 4. 
face. $^{38}$

Although it is clear that the main topic of the inscription is about the custodians and laws applied to them, historians and epigraphers are grappling with the specific purpose of the Stele of Koguryǒ in Ji'an. For example, many scholars in Korea and China argue that the inscription is to list and record households of the custodians assigned for a certain royal tomb, and the stele is one of many stone slabs for Koguryŏ's royal tombs. $^{39}$ On the other hand, some scholars insist that the stele was to announce a code, emphasizing the stele's regulations pertaining to the custodians. As discussed in Chapter 2, there is a similar passage about a law to forbid selling and buying custodians in the Stele of King Kwanggaet'o. According to this passage, King Kwanggaet'o established a law to forbid selling and buying the custodians in his lifetime. Those historians who argue that the Stele of Koguryŏ was erected to announce a law point out that this 'law established in his lifetime' was announced through these steles like the Stele of Koguryŏ in Ji'an. 40

Before this paper further discusses the stele, it is necessary to clarify the erection date of the Stele of Koguryŏ in Ji'an. Generally, those scholars who insist the stele was erected during the reign of King Changsu use the following assumptions as the basis for their argument: first, as "Kukkangsang T'aewang" was a posthumous title for King Kwanggaet'o, the stele had to be made after his death. Second, the fourth to eighth letters on

38 Sŏ, "Kwanggaet'owangrŭngbi Hyejŏngsochangbon."

39 Yeo, "Sinbalgyŏn 〈Chiban'goguryŏbi〉ŭi Kusŏnggwa Naeyong Koch'al," 79; Lee Seongje, " $<$ Chiban'goguryŏbi $>$ ro Pon Sumyoje (System for Tending Tomb from Koguryo Stele in Ji'an)," Han'gukkotaesayŏn'gu (The Journal of Ancient Korean History) 70 (2013): 35.

40 Chang Fuyou, "Jian Maxian Gaojulibei tanzong (A Collective Analysis on the Stele of Koguryŏ in Mazian, Jian)," Shehuikexue Zhanxian (Social Science Front) 5 (2013); Sun, "Chiban Koguryŏpiŭi P'andokkwa Munja Pikyo”; Kim Hyŏnsuk, "Chiban'goguryŏbiŭi Kŏllipsigiwa Sŏnggyŏk (The Construction Date and the Features of Jian Koguryo Stele)," Han 'gukkotaesayŏn'gu (The Journal of Ancient Korean History) 72 (2013). 
the seventh line of the inscription could be interpreted as “丁卯歲刊石," which indicates the erection date should be 427 A.D., or 487 A.D.. Yet, these assumptions, which many historians have already criticized, have too many flaws to confirm that the stele was erected during King Changsu's reign. As noted above, the title "Kukkangsang T'aewang" could be referring to other kings such as King Kogugwŏn or King Kogukyang rather than King Kwanggaet'o; since it is hard to tell if the king in question is King Kwanggaet'o, the title of the king cannot be used as evidence to confirm the erection date of the stele.

Above all, if the inscription was engraved after the erection of the Stele of King Kwanggaet'o, it seems doubtful since there is no passage on the Stele of Koguryŏ in Ji' an referring to the rules and regulations on the other stele. As clearly stated on the Stele of King Kwanggaet'o, the king brought a colossal change to the previous system of the royal tombs' conservation. If so, it is incoherent to omit the narration about King Kwanggaet'o's accomplishments, such as his order to bring the captives from Han and Ye to make the custodians. Certainly, there were remarks about the previous custodians in the newfound stele's inscription, such as onthe third or fourth lines. Since many characters on these lines are illegible, it is hard to affirm that these lines were not describing King Kwanggaet'o's achievements. Yet, considering the overall context of the inscription, these lines could not be about the king's orders to the custodians, as the fifth and sixth line continues with the eulogy for other kings; if there were any mentions about King Kwanggaet'o, it is illogical to engrave any sentences about him before the statements about his preceding kings, especially, when the first and second lines are about the founder of Koguryŏ. Therefore, at this point in time, it would be best to assume that the stele was erected during the reign of King Kwanggaet'o, even if there were many unresolved questions about the inscription. With this assumption, it will be possible to examine the historical background of the erection of the stele, which will help to understand its characteristics. ${ }^{41}$ 


\section{The Rules and Regulations over the Custodians and Koguryŏ in the Fifth Century}

As noted above, one of the most controversial topics about the Stele of Koguryŏ in Ji'an is the stele's relationship with the Stele of King Kwanggaet'o, and this discussion is strongly linked with the debate over the custodians of the royal tombs in Koguryŏ. Many historians in Korea, who argue that the newfound stele was erected during the reign of King Kwanggaet'o, suggest that it is one of the stone slabs the Stele of King Kwanggaet'o stated the king ordered to erect. ${ }^{42}$ From this perspective, the Stele of Koguryŏ in Ji'an is a stele constructed at an ancestor king's tomb "to record the Yŏnho in order to prevent confusion."

Yet, while accepting that the stele was erected during the reign of King Kwanggaet'o, some historians deny the possibility that it was one of the stone slabs the Stele of King Kwanggaet'o mentions. They argue the Stele

of Koguryŏ in Ji'an was not a stone slab to register the custodians, but instead announced the code to prohibit selling and buying of custodians, which was engraved in the last part of the inscription. These historians point out the facts that 1) there is no royal tomb near the area the stele was found (see Figure 4), 2) there is no reference to a specific king or his tomb the custodians were assigned to in the inscription and 3) the inscription illustrates the general ordinance about the custodians. Thus, the stele was not a tombstone to record the custodians of a specific royal tomb, but an announcement of the law vis-à-vis the administration of the custodian system. $^{43}$

41 For more information about the previous researches about the stele, see Yeo, "Han'chung.il Samguk Hakkyeŭi 〈Chiban'goguryŏbi〉. This article reviews and summarizes the overall historiography of the newfound stele until 2016.

42 Kong, "Chiban Koguryŏpiŭi Palgyŏn'gwa Naeyonge Taehan Kochal," 37-42; Cho Pŏpchong, "Chiban'goguryŏbiǔi T'ǔksŏnggwa Sumyoje (The Features of the Stele of Koguryŏ in Jian and Sumyoje)" (paper presented at the conference 〈Sinbalgyŏn Koguryŏbiŭi Yebijŏk Kŏmt'o > by the Institute of Koguryŏ Balhae, Seoul, February 22, 2013), 85-6. 
Figure 4. The Relative Distance from the Excavation Site of the Stele to the Royal Tombs in Ji' $\mathrm{an}^{44}$

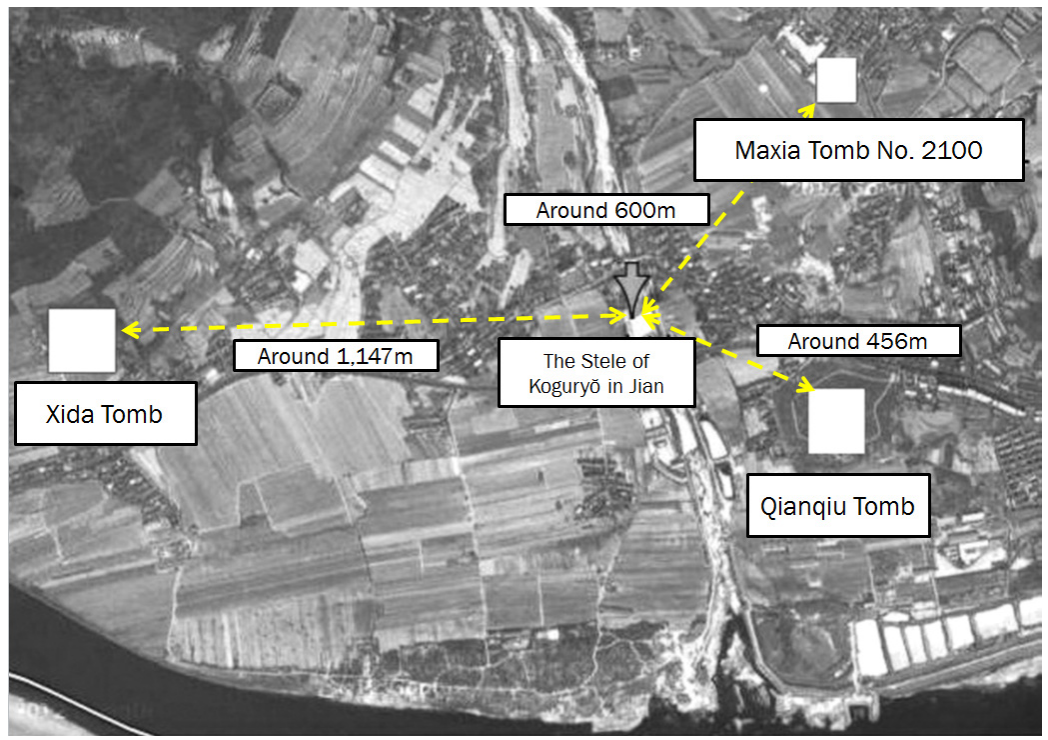

Still, these historians need to respond to the counterarguments that the inscription of the stele presumably contains the names of the custodians, a fact which perfectly corresponds to the characteristic of the stone slabs erected under the order of the king the Stele of King Kwanggaet'o described. If this newfound stele was made to declare a code, the names of the custodians would be unnecessary, since there was a separate stele recording the custodians' names. Furthermore, as there was assuredly an inscription on the back face of the stele as well, it is still possible that a

43 Jung Hosub, "Chiban Koguryŏbiŭi Sŏnggyŏkkwa Chubyŏnŭi Koguryŏ Kobun (The Characteristics of the Stele of Koguryŏ in Jian and the Royal Tombs of Koguryŏ around it)," Han'gukkotaesayŏn'gu (The Journal of Ancient Korean History) 70 (2013): 116-32; Lee Seongje, "〈Chiban'goguryŏbi >ro Pon Sumyoje," 195-211; Zhao, "Chiban Koguryŏbie Nat'anan Wangnŭngjesawa Chosanginsik," 144-51.

44 The map is cited and edited from the image in Kong, "Chiban Koguryŏpi'ŭi Palgyŏn'gwa Naeyonge Taehan Kochal,” 40. 
reference to a specific king or tomb had been engraved on the back face.

To analyze the purpose of the stele, it is worth paying attention to the part in the stele describing how people started to buy and sell the custodians. Although the situation was illustrated in the Stele of King Kwanggaet'o as well, the newly discovered stele especially emphasizes on the phenomenon of selling and buying the custodians and the prohibition against these activities. In fact, this phenomenon could be the cause of the stele's erection, since the inscription specifically describes how people in Koguryŏ performed rituals for their ancestor kings, and the trading of custodians brought disorder and confusion to this tradition. (from $\Pi-18$ to VI-22 in Table 1) If so, it is necessary to question how this 'disorder and confusion' occurred, and why the royal court of Koguryŏ had to forbid the trading of custodians.

As discussed above, a trade of the custodians likely existed between a commoner who was assigned to a custodian and another commoner selling manpower. In other words, those commoners who had enough money hired other commoners and made them to fulfill the duty in the buyers' place. If this kind of duty evasion frequently occurred, it would have inevitably caused 'disorder and confusion' in maintaining the royal tombs, so Koguryǒ's ruling group had to clearly record the identity of the individuals who were assigned to the custodians on stone slabs.

Yet, it is questionable whether this issue existed from the very beginning when Koguryǒ's royal court started to build royal tombs and deploy custodians. According to the Stele of King Kwanggaet'o, the preceding kings had never erected a stele to record names of the custodians, which was the main cause of the problem that later emerged. It is, however, hard to believe the preceding kings did not have the ability or will to erect stone slabs to record the list of the custodians, since their jobs were to look after their ancestors' tombs. ${ }^{45}$ Possibly, even if the custom of trading

45 Lim Ki Hwan points out that it is unlikely the royal court of Koguryŏ should have at least enough power to reorganize the custodian system, even under the assumption that the authority of the court had been diminished during this period. See Lim, 
custodians existed during the other kings' reigns, it was not as serious as to compel Koguryŏ's ruling class to resolve the problem. Around the fourth century, the ruling class finally realized the turmoil and sought for a solution, which caused them to erect a stele to record the custodians' names.

Why did this phenomenon suddenly become an issue during this period when the problem was not regarded as serious as to force the royal court of Koguryŏ to strictly record the workers? At this point, the royal court of Koguryŏ repeatedly issued orders to forbid the selling and buying of workers for the tombs, which signifies that the phenomenon of trading the custodians was prevalent in Koguryŏ. Taking into account the fact that those who were assigned to the job were commoners in Koguryŏ, it is possible to say the custodian duty was a kind of statute labor. If this is true, then the phenomenon of "selling and buying" people who had been obligated to a statute labor was not limited to the custodian duty, since the job was for the tombs of their kings. As is well known, building and preserving royal tombs in ancient states like Koguryŏ was assuredly the highest priority for the ruling class. If there was a phenomenon that commoners had dodged such an important duty through payoffs nevertheless, it would not have been difficult for them to avoid other statute labors such as building castles or military service.

Although there is no historical text to show Koguryŏ's statute labors or policies related to them during this period, the preceding kings would have presumably attempted to forestall such duty evasion. Still, they had never gone as far as to erect steles to register the names of the custodians, because the problem had not been considered as a serious issue for the ruling class of Koguryŏ, as long as the labor pool was large enough to meet the demands of statue labor.

Yet, Koguryŏ would hypothetically suffer from a shortage of manpower around the late fourth century, and the ruling class had to reorganize their populace to secure the necessary manpower. Around the fourth cen-

“Koguryŏ Chipkwŏnch'eje,” 176-7. 
tury, the states on the Korean Peninsula like Koguryŏ and Paekche competitively launched wars against each other in order to expand their territory and secure manpower. Consequently, the states needed to mobilize an army on a larger scale. Since the kingdom had to carry out wars against almost all neighborhood states, Koguryŏ repeatedly mobilized tens of thousands of soldiers in multiple battles, inevitably demanding more manpower than they had used before. ${ }^{46}$

The wars against the other states, however, did not proceed well for Koguryŏ in the middle of the fourth century and possibly caused a serious shortage of manpower, which could be seen in the following text from Samguksagi:

(B-1)

(In the $12^{\text {th }}$ year of King King Kogugwŏn [342 A.D.]), November, Murong Huang (慕容徨) led a strong army of 40,000 himself and (...) invaded Koguryǒ. (...) (Murong Huang) dug King Mich’ŏn (美川王)'s tomb, and pillaged treasures handed down for generations. Then (Murong Huang's army) burned down the palace, destroyed Hwando Castle (丸都城), and returned (to their kingdom), taking 50,000 men and women as captives. ${ }^{47}$

According to this record, Koguryŏ suffered utter defeat against the Yan (燕) dynasty in 342, and momentarily lost their capital city. The Yan army pillaged the palace and returned to their kingdom capturing 50,000 residents of the city. Considering the number of the captives and the overall population of Koguryŏ at this period, it would have been a severe loss to Koguryŏ's infrastructure. Further, Koguryŏ had to undergo another crush-

46 Kim Yŏngha, "Samguksidae Wangŭi T'ongch'ihyŏngt'ae Yŏn'gu (A Study on the Form of the Kings' Ruling during the Three Dynasties Period)" (PhD diss., Korea University, 1988), 126.

47 Samguksagi 18, Annals of Koguryŏ, Nov. the $12^{\text {th }}$ year of King Kogugwŏn. 
ing defeat in a battle against Paekche in $369,{ }^{48}$ and the king's death in battle two years later. ${ }^{49}$ Although Koguryŏ resurged and reached its apex through active militaristic expansions during the reign of King Kwanggaet'o, it is imaginable that a series of defeats would have caused a shortage of manpower in Koguryŏ for quite a time.

The battle against Paekche in 369 did not only additionally damage Koguryŏ's labor force, but points to the possibility that Koguryŏ had already suffered a shortage of manpower around the middle of the fourth century:

\section{(C-1)}

King Kusu, his given name is Hwi, is the son of King Kŭnch'ogo. Previously, Sayu, Koguryŏ's King of Kukkang, invaded (Paekche) himself, King Kŭnch'ogo sent his crown prince (King Kusu) to defend. Arriving at Pan'gŏl yang, (the prince) was about to begin the battle. Sagi, a person from Koguryŏ, was originally a person of Paekche. (He) wounded a hoof of the king's horse by mistake, and fled to Koguryŏ, fearing that he may receive a punishment. He came back to (Paekche) at this time and said to the crown prince that "although Koguryŏ's army has a large number, all of them were decoy troops (疑兵). The strongest (unit in the army) is the one with a red flag. If (we) crush this first, then the rest of them will crumble away themselves." The crown prince followed this (advice), marched and smashed (Koguryŏ's army). ${ }^{50}$

This record of the Annals of Paekche in Samguksagi illustrates the battle between Koguryŏ and Paekche in 369. According to this text, Koguryŏ had a battle against Paekche with decoy troops (疑兵), which was only to exaggerate the number of the army. Yet, Paekche saw through the reality

48 Samguksagi 18, Annals of Koguryŏ, Sep. the $39^{\text {th }}$ year of King Kogugwŏn.

49 Samguksagi 18, Annals of Koguryŏ, Oct. the $41^{\text {th }}$ year of King Kogugwŏn..

50 Samguksagi 24, Annals of Paekche, Nov. the $1^{\text {st }}$ year of King Kŭn'gusu. 
of Koguryŏ's army and defeated them in the battle of Pan'gŏl yang. Kim Hyŏnsuk suggests that these "decoy troops" were probably an army recruited from among the local residents of the conquered territory. They inevitably lacked training and, above all, loyalty to Koguryǒ's king, which was the main reason for Koguryŏ's defeat. If we accept this interpretation, it is possible to assume that Koguryŏ was in a situation to desperately require manpower, which compelled the leaders of the kingdom to mobilize any troops regardless of their condition. ${ }^{51}$ Admittedly, the record cannot concretely prove that Koguryo suffered a shortage of manpower at this period; still, it would not be too far-fetched to think that the leaders of Koguryŏ had to deliberately seek for a method to secure manpower to continue militaristic expansion.

To further secure manpower, it was necessary for Koguryŏ to establish a more centralized government. Historians generally agree that the late fourth century was an age of reform for Koguryŏ to reorganize the political and social system under a centralized administration. Installing a unified official ranking system (官等制) at this period could be considered as one of these policies, as it could efficiently absorb the new residents of the conquered territory into Koguryŏ's hierarchical order. ${ }^{52}$ Also, unlike the participants in previous wars who were limited to small elite groups, the commoners started to join the wars after the fourth century, which was the result of mobilizing every resident through the military service system under the centralized authority. ${ }^{53}$

In consideration of the political and social changes in Koguryŏ, it is possible to suggest that the situation forced the royal court to strictly re-

51 Kim Hyŏnsuk, Koguryŏŭi Yŏngyŏkchibaebangsik Yŏn'gu (A Study on Koguryŏ's Method of Ruling over the Territory) (Seoul: Mosinŭnsaramdŭl, 2005), 155-6.

52 Takeda Yukio, Koukuli to Higashi Ajia (Koguryŏ and East Asia) (Tokyo: Iwanami Shoten, 1989), 370; Lim Ki Hwan, Koguryŏ Chŏngch'isa Yŏn'gu (A Study on the History of Koguryǒ's Politic) (Seoul: Hannarae, 2004), 237-9.

53 Lee Kibaek, “Koguryoŭ̌i Kyŏngdang: Han'guk Kodaegukkae Issŏsŏŭi Misŏngnyŏnjiphoeŭi Iryuje (Kyongdang in Koguryo: An example of legacies of primitive age-grade societies in ancient Korea)," Yǒksahakpo 35•36 (1967). 
organize the residents, and prevent anything to cause duty evasion. The law to forbid 'trading' the custodians was probably one of these policies, and as a result, King Kwanggaet'o ordered to erect steles to announce the law. Yet, the shortage of manpower could not be solved by simply securing labor force from the original residents in Koguryŏ, since the fundamental cause was a decrease in manpower because of the defeats in wars against Yan and Paekche. This issue would have been particularly serious in the capital city, as the war against the Yan dynasty brought the loss of 50,000 residents, who were a potential labor force for the statute duties in the area. The lack of labor meant heavier pressure on the original residents of Koguryŏ, a situation which corresponds to the Stele of King Kwanggaet'o's statement that the king "worried that these Old People (the original residents of Koguryŏ) will be gradually impoverished." Therefore, King Kwanggaet'o ordered to bring the residents in Han and Ye to the capital and use them as custodians, implying the pre-existence of the various practices of Koguryŏ's ruling class to resolve the shortage of manpower.

In this sense, it is possible to understand the ultimate purpose of the hyperbolic narration about the king's martial achievements in the Stele of King Kwanggaet'o. The term Han (韓) generally refers to people in the southern part of the Korea Peninsula, including Paekche. This means a certain number of the custodians were captives from Paekche. The inscription illustrates that King Kwanggaet'o conquered the territories of Paekche, and the 'Sinmyo year passage' is a part of these achievements. If so, the passage would inevitably exaggerate the captives' subordinate position, by describing Paekche and Silla as subject states to Koguryŏ. By claiming that they were invaded and surrendered to Japan, the passage justified the king's invasion of Paekche and Silla, and emphasized the custodians' position as subordinates. 


\section{Conclusion}

The Stele of Koguryŏ in Ji'an is a stone slab erected by the royal court of Koguryŏ to record the names of the royal tombs' custodians, and announce regulations that applied to them. Considering the content related to the Stele of King Kwanggaet'o's demonstration of the custodian system (Sumyoje), the newfound stele is a valuable source to reinterpret the system. Furthermore, as there is presumably a time difference between these steles, the Stele of Koguryŏ in Ji'an will help to understand the process of the system's development.

To summarize this paper's argument, the Stele of Koguryŏ in Ji' an was a part of Koguryŏ's policy to reorganize their control over the inhabitants and overcome the shortage of manpower. Although "selling and buying" the custodians and, ultimately, statute labors had been habitually practiced in Koguryŏ, the ruling class of Koguryŏ recognized the necessity to forbid this practice in the process of regrouping the inhabitants around the fourth century. Yet, the shortage of manpower could not be solved by simply reorganizing the original residents, so King Kwanggaet'o sought for an alternative solution to resolve the issue, namely transferring residents from conquered territories.

Although the discussion about the Stele of Koguryor in Ji'an still has many problems waiting to be solved such as deciphering illegible characters, a number of studies have already contributed new perspectives on the custodians of Koguryŏ. Yet, most of the historians in Korea and China who pay attention to Koguryǒ's custodian system in these two steles have focused on the groups of people who were assigned to the job, implying that they were particularly selected groups distinct to the commoners in Koguryŏ. Even if this is true, it is hard to imagine the historical aspects in these steles such as the trading of custodians or enacting a prohibition against the duty evasion were exceptional phenomena. Thus, it is necessary to study the stele from the broader perspective of what the stele reveals regarding Koguryŏ's social situation during this period. 
Figure 5. Rubbing of the Stele of Koguryŏ in Ji'an (made by Zhou Rongshun in 2012)

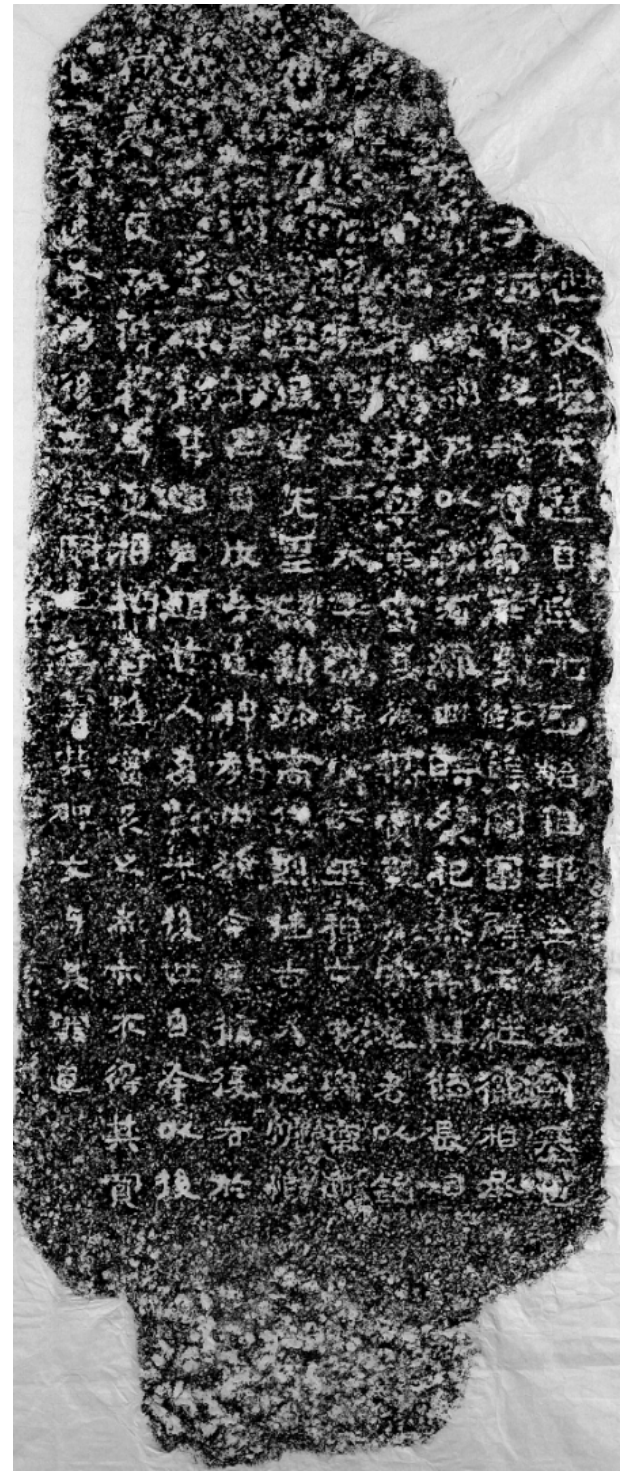




\section{References}

1. Chang, Fuyou. "Jian Maxian Gaojulibei Tanzong (A Collective Analysis on the Stele of Koguryŏ in Mazian, Jian)." Shehuikexue Zhanxian (Social Science Front) 5 (2013).

2. Cho, Bŏpchong. "Chiban'goguryŏbiŭi T'ŭksŏnggwa Sumyoje (The Features of the Stele of Koguryŏ in Jian and Sumyoje)." Paper presented at the conference 〈Sinbalgyŏn Koguryŏbiŭi Yebijŏk Kŏmt'o〉 by Institute of Koguryo Balhae, Seoul, February 22, 2013.

3. Hong, Seung-Wo. " $<$ Chiban'goguryŏbi >e Nat'anan Koguryŏ Yullyŏngŭi Hyŏngsikkwa Sumyoje (Law Codes and System for guarding and managing royal tombs of Goguryeo, reflected upon Jian-Goguryeo-Stele)." Han'gukkotaesayŏn'gu (The Journal of Ancient Korean History) 72 (2013): 83-117.

4. Inoue, Naoki. "Ilbonhakkyeesŏŭi Kwanggaet'owangbi Yŏn'guŭi Sŏnggwawa Kwaje (Results and Topics in Japanese Research on the Epitaph of King Gwanggaeto)." Tongbugayŏksanonch'ong 49 (2015): 201-38.

5. Jian City Museum, ed. Ji'angaojulibei (The Stele of Koguryŏ in Jian). Changchun: Jilindaxue Chubanshe, 2013.

6. Jo, Yeongkwang. "Kwanggaet'owangbie Poinŭn Taeoe Kwan'gyewa Koguryŏ Ch'ŏnhagwane Taehan Yŏn'gu Hyŏnhwanggwa Kwaje (Status and Tasks for Study of the Foreign Relations and World View of Koguryŏ in the Kwanggaet'o Stele)." Tongbugayŏksanonch'ong 49 (2015): 47-86.

7. Jung, Hosub. "Chiban Koguryŏbiŭi Sŏnggyŏkkwa Chubyŏnŭi Koguryŏ Kobun (The Characteristics of the Stele of Koguryŏ in Jian and the Royal Tombs of Koguryŏ around it)." Han'gukkotaesayŏn'gu (The Journal of Ancient Korean History) 70 (2013): 101-38.

8. Jung, Hosub. 'Kwanggaet'owangbiŭi Hyŏngt'aewa Wich'i, Pimun Kusŏnggwa Sŏnggyŏge Kwanhan Yŏn'gu Sŏnggwawa Kwaje (Research on the King Kwanggaet'o Stele and Future Tasks: Regarding Morphology, Location, Content Structure, and Features)." Tong- 
bugayŏksanonch'ong 49 (2015): 11-46.

9. Kang, Jin-won. 'Sinbalgyŏn 'Chiban'gokuryŏpi'ŭi P'andokkwa Yŏn'gu Hyŏnhwang: Yakkanŭi Nukyŏnŭl tŏtpuch'yŏ(Reading and Analyzing the Newly Discovered JianGoguryeo Bi: Report of Current Research Situation and the Author's Personal Opinion)." Mokkan'gwa Munja (Wooden Documents and Inscriptions Studies) 11 (2013): 105-34.

10. Kim, Hyŏnsuk. 'Kwanggaet'owangbirŭl T'onghaepon Koguryŏsumyoinui Sahoechŏk Sŏnggyŏk (The Social Characters of the Tomb Keepers Illumined through the Great King Kwanggaet'o's Stele)." Han'guksayŏn'gu (The Journal of Korean History) 65 (1989): 1-36.

11. Kim, Hyŏnsuk. Koguryŏŭi Yŏngyŏkchibaebangsik Yŏn'gu (A Study on Koguryŏ's Method of Ruling over the Territory). Seoul: Mosinŭnsaramdŭl, 2005.

12. Kim, Hyŏnsuk. "Chiban'goguryŏbiŭi Kŏllipsigiwa Sŏnggyŏk (The Construction Date and the Features of Jian Koguryo Stele)." Han'gukkotaesayŏn'gu (The Journal of Ancient Korean History) 72 (2013): 5-35.

13. Kim, Rak Ki. "Kwanggaet'owangbi Sumyoinyŏnhojoŭi Yŏn'guhyŏnhwanggwa Kwaje [The Current Status and Tasks of Sumyoin-yunho(守墓人烟戶) in King Gwanggaeto stele].” Sŏnsawa kodae (Prehistory and Ancient History) 47 (2016): 31-58.

14. Kim, Sŏkhyŏng. Ch'ogijoilgwan'gyesa (The Early Korean-Japanese Relationship). Pyongyang: Sahoekwahagwŏn Chulp'ansa, 1966.

15. Kim, Yŏngha. "Samguksidae wangŭi t'ongch'ihyŏngt'ae yŏn'gu (A Study on the Form of the Kings' Ruling during the Three Dynasties Period)." PhD diss., Korea University, 1988.

16. Kong, Seok-koo. “'Chiban Koguryŏpi'ŭi Palgyŏn'gwa Naeyonge Taehan Kochal (The Discovery and Analysis of Koguryo Tombguarding Monument).” Koguryŏ Palhae Yŏn'gu 45 (2013): 27-54.

17. Koguryŏyŏn'guhoe, ed. Kwanggaet'ohot'aewangbi Yŏn'gu 100nyŏn (100 Years of Studies about the Stele of King Kwanggaet'o). Seoul: Hagyŏnmunhwasa, 1996. 
18. Lee, Jeongbin. “Kwanggaet'owangnŭngbi T'akpon Yŏn'gubangbŏbŭi Sŏnggwawa kwaje (Research Methods for Rubbings of the Gwanggaeto Stele).” Tongbugayŏksanonch'ong 49 (2015): 87-113.

19. Lee, Kibaek. "Koguryŏŭi Kyŏngdang: Han'guk Kodaegukkae Issŏsŏŭi Misŏngnyŏnjiphoeŭi Illyuje (Kyongdang in Koguryo -An example of legacies of primitive age-grade societies in ancient Korea)." Yǒksahakpo 35•36 (1967): 42-54.

20. Lee, Seongje. "〈Chiban'goguryŏbi $>$ ro Pon Sumyoje (System for Tending Tomb from Koguryo Stele in Ji'an)." Han'gukkotaesayŏn'gu (The Journal of Ancient Korean History) 70 (2013): 181-218.

21. Lee, Yŏngho. "Chiban Koguryŏbiŭi Palgyŏn'gwa Sogae (Discovery and Introduction of The Stele of Koguryŏ in Jian)." Han'gukkotaesayǒn'gu (The Journal of Ancient Korean History) 69 (2013): 297-311.

22. Lim, Ki Hwan. “Koguryŏ Chipkwŏnch'eje Sŏngnipkwajŏngŭi Yŏn'gu (A Study on the Process of Koguryǒ's Formation of the Centralized System).” PhD diss., Kyŏnghui University, 1995.

23. Lim, Ki Hwan. Koguryŏ Chŏngch'isa Yŏn'gu (A Study on the History of Koguryǒ's Politic). Seoul: Hannarae, 2004.

24. Noh, Tae don. "Kwanggaet'owangbi." In Yǒkchu Han'gukkotaekŭmsŏkmun 1 (Ancient Epigraph of Korea, Vol.1), edited by Han'gukkotaesahoeyŏn'guso. Seoul: Karakkuksachŏkkaeparyŏn'guwŏn, 1992.

25. Park, Chinsŏk. Koguryŏ Hot'aewangbi Yŏn'gu (A Study on Hot'aewangbi of Koguryŏ). Seoul: Aseamunhwasa, 1996.

26. Park, Sihyŏng. Kwanggaet'owangrŭngbi (The Stele for the Royal Tomb of King Kwanggaet'o). Pyongyang: Sahoekwahagwŏn Chulp'ansa, 1966.

27. Sŏ, Yŏngsu. “Kwanggaet'owangrŭngbi Hyejŏngsochangbon: Konggaeŭi Ǔiŭiwa Kŭ Sŏnggyŏk (The Meaning of the Opening to the Public of the Rubbing-inscription from the Original Tombstone for the Great King Kwanggaet'o Housed by Hye-Jung)." Pangmul- 
gwanhakpo (Journal of Museum Studies) 23 (2012): 63-94.

28. Son, Yŏngjong. "Kwanggaet'owangnŭngbimune Poinŭn Sumyoinyŏnho Ŭi Kyegŭpchŏk Sŏnggyŏkkwa ribyŏkpangsige taehayŏ (About the Sumyoin yŏnho's Hierarchical Characteristic and the Method to Carry out the Duty Reflected on the Stele of King Kwanggaet'o).” Ryǒksagwahak (Historical Science) 3 (1986).

29. Sun, Renjie. "Chiban Koguryŏpiŭi P'andokkwa Munja Pikyo (Interpretation and Cross-checking of letters, of the Jian Tablet of Koguryo)." Han'gukkotaesayŏn'gu (The Journal of Ancient Korean History) 70 (2013): 219-47.

30. Takeda, Yukio. Koukuli to Higashi Ajia (Koguryŏ and East Asia). Tokyo: Iwanami Shoten, 1989.

31. Yeo, Ho-Kyu. "Sinbalgyŏn 〈Chiban'goguryŏbi>ŭi Kusŏnggwa Naeyong Koch'al (Examination of the Composition and Contents of the Newly found 〈Koguryo Tablet of Jian〉)." Han'gukkotaesayŏn'gu (The Journal of Ancient Korean History) 70 (2013): 51-100.

32. Yeo, Ho-Kyu. "Han·chung-il Samguk Hakkyeŭi <Chiban'goguryŏbi> Yŏn'gudonghyanggwa Kwaje (Current status and future prospects of studies dealing with the Koguryo Tablet at Jian in Korea, China, and Japan).” Tongbanghakchi 177 (2016): 125-72.

33. Yun, Yong-gu. 'Jian Koguryŏpiŭi T'akpongwa P'andok (Rubbing and Deciper of the Stele of Koguryŏ in Ji'an)." Han'gukkotaesayŏn'gu (The Journal of Ancient Korean History) 70 (2013): 5-49.

34. Xu, Jian-xin. "Zhongguo xinchu Jiangaolulibei shixi (Analysis on the Newly Found the Stele of Koguryŏ in Ji'an of China)." Dongbeishidi (東北史地) 2013-3 (2013).

35. Zhao, Yu-Ran. "Chiban Koguryŏbie Nat'anan Wangnŭngjesawa Chosanginsik (The Ritual of Royal Tombs and Perception of Former Kings Reflected in "The Ji-an Koguryo Stele)." Han'gukkotaesayŏn'gu (The Journal of Ancient Korean History) 70 (2013): 139-79. 
36. Cho, Wooyun(Zhao, Yu-Ran). "Chunggukhakkyeŭi Kwanggaet'owangbi Yŏn'gu Sŏnggwa Kŏmt'o (Review of Historical Research on the King Kwanggaet'o Stele by Chinese Academics)." Tongbugayǒksanonch'ong 49 (2015): 115-99. 


\section{An Analysis on the Contents of the Stele of Koguryo in Ji'an with Regard to Koguryŏ's Reorganization of Sumyoje}

Jong-Rok Lee

Despite a considerable amount of research focused on Koguryǒ's Sumyoje (守 墓制), there are many unsolved issues regarding the characteristics of the custodians of the royal tombs because the Stele of King Kwanggaet'o has been the only source to examine the system. In this sense, the Stele of Koguryŏ in Ji'an (集安高 句麗碑; Chiban Koguryŏbi in Korean)," found in 2012, provides an opportunity to reinterpret the system, drawing scholarly attention to Koguryŏ's Sumyoje again.

Although the date and purpose of the stele is still amidst debate, historians generally agree that the purpose of the stele is related to the custodians for the royal tombs. Naturally, most of the recent articles on the newfound stele have addressed this system, broadening our perspective on Koguryŏ's domestic administration. This paper, based on the interpretations and arguments of previous studies, argues that the Stele of Koguryŏ in Ji'an was a part of Koguryŏ's general policy to reorganize their control over their inhabitants and overcome the shortage of manpower. Under the hypothesis that "selling and buying" the custodians and, ultimately, statute labors had been habitually practiced in Koguryŏ before this time, it is possible that the ruling class of Koguryŏ recognized the necessity to forbid this custom around the fourth century as the kingdom suffered a shortage of manpower especially after the continuous wars against the Yan dynasty and Paekche.

Keywords: the Stele of Koguryŏ in Ji'an, the Stele of King Kwanggaet'o, Sumyoje, King Kwanggaet'o, statute labor, centralized government system 


\section{〈국문초록〉}

\section{高句麗의 守墓制 재정비에 관한 集安高句麗碑의 碑文 검토}

이종록 (고려대 한국사학과 박사과정수료)

高句麗의 守墓制에 관해서는 지금까지 학계에 다양한 연구가 이루어져 왔으나, 수묘제의 운영과 그 구성원에 대해서는 여전히 해결되지 않은 여러 문제들에 대 해 논란이 있다. 이러한 논란의 원인 중 하나는 廣開土王碑를 제외하면 관련 사료 가 한정되어 있기 때문이었다. 그러나 2012년 集安高句麗碑의 발견으로 인해 수 묘제에 대한 논의가 다시 활성화되는 동시에, 기존의 수묘제에 대한 해석에도 재 고의 여지를 주게 되었다.

비록 집안고구려비의 建碑 연대 및 목적에 대해서는 견해가 엇갈리고 있으나, 기본적으로 이것이 당대의 수묘제와 깊은 관련이 있다는 것은 분명하다. 따라서 지금까지의 이 비에 관한 연구들은 수묘제에 관해 주로 논하는 경우가 대부분이 며, 이에 따라 비의 발견 이후 짧은 기간 동안에 다양한 학설이 제시되어 왔다. 본고에서는 집안고구려비에 관한 기존의 논의를 검토하는 동시에, 이를 토대로 광 개토왕비에서 전하는 수묘제 재정비의 배경에 대해 별도의 가능성을 제기해 보았 다. 곧 비문의 守墓人 賣買 禁止 조항이 단지 수묘제에 한정된 문제가 아닌, 당대 고구려의 주민집단의 재편과 인력 부족을 극복하기 위한 정책의 일환이었다고 추 정하였다. 이는 두 비문에서 공통적으로 언급하는 수묘인 매매가 워수슬에 한정된 관행이 아니라 고구려의 力役動員體制에서 전반적으로 나타나고 있던 현상이라는 가정으로부터 도출된 결론이다. 그리고 이 관행의 문제점을 인지한 고구려의 지배 집단에 의해 집안고구려비와 같은 매매 금지령의 시행되었으며, 이는 4세기 무렵 前燕 및 百濟와의 전쟁으로 야기된 인력부족 현상을 극복하기 위한 노력의 일환 이었다고 이해된다.

주제어: 집안고구려비(集安高句麗碑), 광개토왕비(廣開土王碑), 수묘제(守墓制), 광개토왕(廣開土王), 국역(國役), 중앙집권체제 
